\title{
The Impacts of Climate Change on the Availability of Surface Water Resources in Jordan
}

\author{
Elias Salameh* (D), Ghaida Abdallat \\ University of Jordan, Amman, Jordan \\ Email: *salameli@ju.edu.jo
}

How to cite this paper: Salameh, E., \& Abdallat, G. (2020). The Impacts of Climate Change on the Availability of Surface Water Resources in Jordan. Journal of Geoscience and Environment Protection, 8, 52-72.

https://doi.org/10.4236/gep.2020.810004

Received: September 2, 2020

Accepted: October 12, 2020

Published: October 15, 2020

Copyright $\odot 2020$ by author(s) and Scientific Research Publishing Inc. This work is licensed under the Creative Commons Attribution International License (CC BY 4.0).

http://creativecommons.org/licenses/by/4.0/

\begin{abstract}
Climate change in the Middle East area including Jordan has started to be reflected in decreasing precipitation and increasing temperatures with their impacts on the availability of surface and groundwater. This article aims to evaluate the impacts of decreasing or increasing precipitation by $10 \%$ and $20 \%$ on the quantities of flood runoff based on recorded precipitation and runoffs of catchments during the past 60 to 70 years of observation, during which the precipitation in individual or a few years increased or decreased by tens of percentages relative to the long-term average precipitation. The results of quantification show that in Jordan as a whole, decreasing precipitation by $10 \%$ and $20 \%$ has historically (during the recording period) resulted in reductions in flood flows by $26.2 \%$ and $52.8 \%$ and that increasing precipitation by $10 \%$ and $20 \%$ has resulted in increases in flood flows by $26.4 \%$ and $56.5 \%$ respectively. These results look somehow paradox, because the general perception is that flood runoff changes in the same percentage like precipitation although flood flow is not linearly correlated with precipitation but exponentially. Decreasing precipitation in the water-scarce stressed country, Jordan due to climatic changes, will have strong implications on rain-fed and irrigated agriculture and on household water supplies with very severe socio-economic percussions expressed in increasing unemployment and poverty which may lead to social and political unrest. Therefore, proactive measures have to be implemented before disasters hit. Such measures are limited in Jordan to seawater desalination, intensified water harvesting and improved water use efficiency in agriculture.
\end{abstract}

\section{Keywords}

Climate Change Impacts, Precipitation-Runoff Ratios, Surface Water, Socio-Economics 


\section{Introduction}

Climate changes directly affect the quantity and quality of water resources due to changes in the distribution of climatic events (EPA, 2014; Houghton, Jenkins, \& Ephraums, 1990). Moreover, rainfall, temperatures and intensity of rainfall events in Jordan show that climate change has started affecting the country's precipitation $(P)$ and temperatures. Decreasing precipitation has strong negative percussion on the availability of water resources and hence the water supply for all water use sectors, which in turn have negative impacts on the health, environment and socio-economic sectors (Hansen \& Sato, 2011). A simulation study for the period 2040-2099 and based on precipitation records (1961-1990) for the eastern Mediterranean and Middle East region, found that Jordan's precipitation will decrease by $17 \%$ in the middle of this century and by $21 \%$ at its end (Chenoweth et al., 2011). Furthermore, a regional climate model used to investigate changes in Israel and Jordan precipitation predicted dryness as a result of reduction in both the frequency and duration of rainy events (Black, 2009).

Decreasing availability of the quantitatively inelastic household water supply will be, from a management point of view, covered by allocating less water for the agricultural sector, which will also suffer from decreasing precipitation and hence decreasing available surface water amounts. Even, if household and industrial water become enhanced by allocating new sources (desalination of seawater or water import from other countries), the agricultural sector will still suffer from the consequences of climate change. For instance, warmer temperatures will lead to a more energetic hydrological cycle; that turns into possibilities for further dryness and/or floods in some areas and less severe droughts and/or floods in other areas as predicted by the Intergovernmental Panel on Climate Change (IPCC) (Houghton, 1996). However, the IPCC fourth assessment report proposed that the eastern Mediterranean region would become significantly drier under a future climate situation (IPCC, 2007).

In Jordan, several studies showed the impacts of climate change on runoff water and groundwater (Abu-Allaban et al., 2014; Al-Zu'bi, 2009; Smadi \& Zghoul, 2006; Smiatek et al., 2011). Abdulla and Eshtawi (2015) studied the climate change impacts on runoff, sediments and groundwater recharge for King Talal Dam watershed using the SWAT model under different scenarios. The scenarios included: $\pm 20 \%$ change in rainfall, and $1^{\circ} \mathrm{C}, 2^{\circ} \mathrm{C}$ and $3.5^{\circ} \mathrm{C}$ increases in average temperature. The study showed that climate warming can impact runoff, groundwater recharge and sediment yield in the basin, which will also be greatly influenced by changes in rainfall volume.

Therefore, the Jordanian government in 2015 originated Jordan's $2025 \mathrm{Na}$ tional Vision and Strategy (NVS), which involves more than 400 policies on environment and climate change (Bany Yasin, 2018; EcoPeace, 2019) beside the socio-economic policies (USAID, 2017). The NVS covered a list of measures for adaptation concerning the environment, food, agriculture, water, and energy. It additionally recognized, as superiority, the development of a legislative frame on climate change to maximize each benefit, minimize the negative influences, and 
build up national capacity. In its summary, the study emphasizes the necessity of security and solid management of resources such as water, energy, food, and agriculture. Further details of Jordan's environmental policies and engagement on climate change are reported by Combaz (2019).

The flood flow of a catchment area depends on a variety of factors such as rainfall type (rain, snow), its intensity and duration, topography, geology (the type of rocks structures and dip angels), soil type and land use. For any defined catchment area topography, geology, soil cover and to some extent land use remain the same for tens of years unless radical changes take place. Therefore, and a result of that, flood flow remains only a function of the type of rain, its intensity and duration (Houghton, 1996; IPPC, 2007). The interplay of these factors with the soil conditions plays also a role in the amounts of resulting flood flows and their correlation with precipitation amounts.

If flood runoff and precipitation are correlated for many years with high, medium and low amounts of rainfall over a catchment, then correlation can be established between runoff and rainfall, and hence, for long-term correlations, dependence is found between runoff amounts and precipitation amounts.

In Jordan precipitation is recorded in more than 250 rainfall stations, operated by the Department of Meteorology (DoM) and about 150 additional stations operated by the Ministry of Water and Irrigation (MWI). Wadi and river runoffs are also recorded for all major and medium discharge wadis and rivers covering all catchment areas. The number of gauging stations was around 150 in the seventies of the last century, but by now some of them are not operated due to damage or remoteness in desert areas. Runoff and precipitation have also been measured for micro-catchments (one to two $\mathrm{km}^{2}$ in areas) for scientific research (Attour \& Ibbitt, 1966; MoPW \& JCE, 1992; UNDP, 1992; AlKhoury et al., 2009; Odeh et al., 2015).

In this study, the runoff precipitation ratios for the different catchments and the different amounts of actually falling precipitation over them will be used to study the impacts of decreasing or increasing precipitation on the availability of floodwater by using historic data to correlate rainfall and runoff for rain-rich and rain-poor years. The authors think that during pre-developmental eras (before urbanization, construction of roads, buildings, dams and wastewater sewerage and treatment systems, strong utilization of water resources and changes in their flow regimes) rainfall-rich and poor years can easily be correlated to stream flood flows. Such years can form a solid basis to study the impacts of climate change on the availability of surface water, water stored in dams and weirs and green water (soil water) and the implications of such availability on water users and their social and economic situation (Hansen \& Sato, 2011).

\section{Data and Methods}

\subsection{Observed Data}

Long term data, since 1985, on precipitation amounts over catchment areas and 
runoff of wadis have been provided by the Jordanian Ministry of Water and Irrigation and the Department of Meteorology. Additional relevant literature and correlations of catchment's runoffs to precipitation amounts have been calculated. Available data (for the pre-developmental era of most catchments, before the 1990s) of precipitation $(P)$ and flood runoff $(R)$ has also been evaluated to obtain changes in runoff/precipitation ratios $(R / P=r)$ with decreasing or increasing precipitation amounts relative to average precipitation amounts. Averages of precipitation amounts per catchment area were used as a basis to calculate decreases or increases in precipitation amounts by different percentages. Here the National Water Master Plan (NWMP, 1977 and its updates) and different studies carried out to evaluate the discharges of wadies for dam and weir constructions were much helpful for obtaining relevant data. Upon that flood runoff/precipitation ratios have been calculated and their changes with increasing or decreasing precipitation quantified, based on historical records, to analyze the impacts of precipitation as a component of climate change on the generation of floodwater in the different catchment areas of Jordan.

\subsection{Calculation}

For calculating the runoff coefficient $(r)$, the following general equation (Equation (1)) is valid:

$$
\frac{R}{P}=r
$$

where: $P=$ precipitation, $R=$ runoff, $r=$ runoff coefficient, which when differentiated becomes Equation (2):

$$
\partial r=\frac{\partial R}{\partial P}
$$

Hence, $r$ is a function of the amount of precipitation in Million Cubic Meter per year $(\mathrm{MCM} / \mathrm{yr})$ and not a fixed ratio or percentage of precipitation. It increases and decreases with increasing or decreasing amount of rainfall over an area. The correlation of flood runoffs to precipitation is presented in Figure 1 and Figure 2 for selected catchments representing the different geological and climatic zones in Jordan. They show that the flood runoff coefficient " $r$ " of each catchment area is a function of precipitation amount; increasing or decreasing as a result of increasing or decreasing precipitation, although the rate of decrease or increase in " $r$ " relative to the amount of precipitation differs from one catchment to another due to differences in other catchment parameters such as topography, geology, soils etc..

\subsection{Consequence of Changes in Precipitation Amounts}

Changes in the amounts of precipitation falling over an area have the following consequences:

1) Increase or decrease in flood flows

2) Increase or decrease in groundwater recharge 


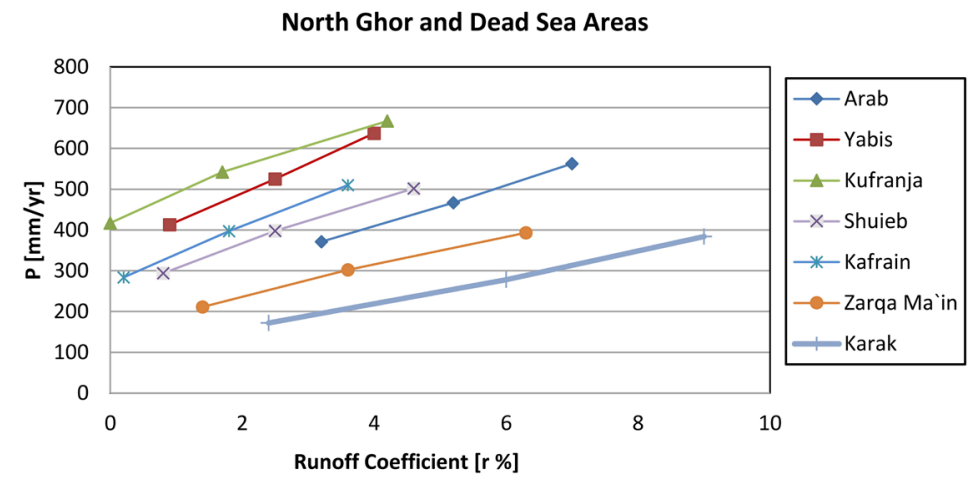

Figure 1. Correlation of precipitation amounts to runoff coefficients for the north Jordan Valley and Dead Sea side wadis based on yearly measurements of precipitation and flood runoffs for series of years with different amounts of precipitation and the resulting flood runoffs.

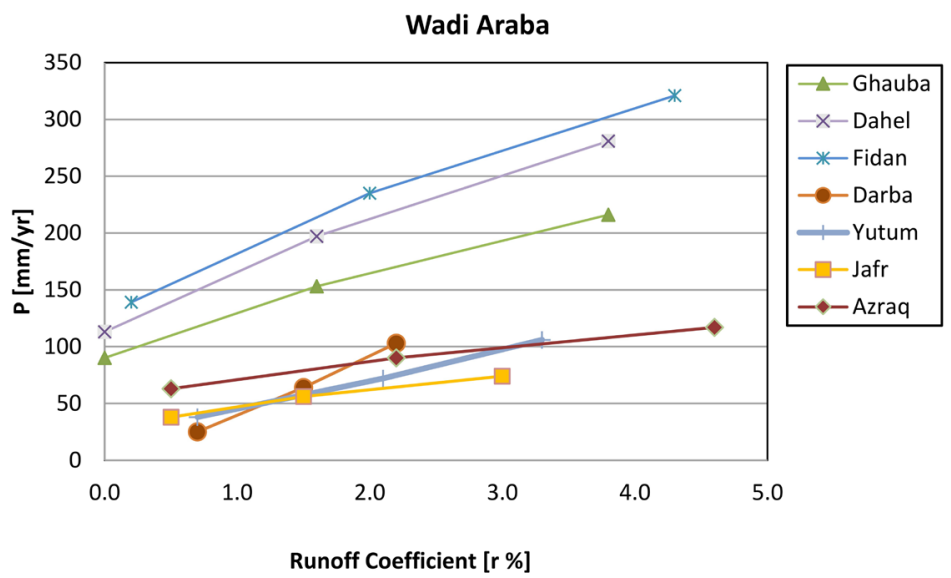

Figure 2. Correlation of precipitation amounts to runoff coefficients for Wadi Araba side wadis and the eastern desert catchments based on yearly measurements of precipitation and flood runoffs for series of years with different amounts of precipitation and the resulting flood runoffs.

3) Increase or decrease in soil moisture content; shorter or longer periods of soils being wetted and shift in agrarian climatic zone regimes

4) Increase or decrease in both surface and groundwater salinities

These consequences have further implications on the availability of surface and groundwater, rain-fed agriculture, water management and ecology. In this article, only the effects of changes in precipitation amounts on floodwater amounts will be discussed.

As already mentioned in the introduction flood flow of an area reflects many characteristics of that area such as topography, geology, soil cover and land-use, which may be reflected in increases or decreases in flood generation. For instance, buildings and road construction result in increasing flood generation, whereas planting trees and plowing soils result in decreasing flood flows. In many areas in Jordan land-use has dramatically changed, especially as a result of extension in urban areas and increasing industrial activities. Both incorporating 
the construction of extensive road-nets and buildings and cementing or asphalting huge land areas all of which lead to changes (increases) in the flood flow to precipitation ratios. When such impacts are superimposed by increasing or decreasing precipitation, then quantification of flood runoff ratios becomes complicated and requiring detailed measurements. Hence, the pre-development eras with the recorded rainfall and runoff data are used in this work because the records contain fair accounts of rain-rich and rain-poor years and the resulting flood amounts for the different catchment areas of the country. Included in this study are the different major catchment areas in Jordan such as the Jordan Valley catchments with the Yarmouk and Zarqa Rivers' catchments, the Dead Sea catchments such as Mujib, Wala, Hasa, Zarqa Ma'in and Karak, Wadi Araba catchments such as Fifa, Dahal, Fidan, Wadi Musa and Yutum and the desert catchments such as Azraq, Jafr and Disi.

Flood runoff/precipitation ratios have been calculated for all major catchments in Jordan in different studies such as Attour and Ibbitt (1966); National Water Master Plan (NWMP) of Jordan 1977 and updates; UNDP (1992); McDonald and Partners (1965); Japan International Cooperation Agency (JICA) Ministry of Planning (1987). In addition, many M.Sc. and Ph.D. theses and studies carried out for the construction of dams have also correlated runoff and precipitation. Moreover, the evaluation of flood runoffs and areas' precipitation has been carried out within the present study. The correlation of areas' precipitation to runoff is generally a straight or slightly convex line, very close to a linear line for the normal range (exempting extreme events) of precipitation in the individual catchments. The correlation shows that the yearly amount of flood flow in a certain area is a function of two variables namely; precipitation amount and the corresponding ratio of flood runoff amount to areas precipitation amounts (Table 1).

Table 1. Maximum, average and minimum annual precipitation amounts and the corresponding runoff amounts for the catchment areas of: the Eastern Jordan Valley side wadis, the flat area of the eastern Jordan Valley, the Dead Sea eastern catchments, the desert catchments and the eastern Wadi Araba side wadis.

\begin{tabular}{lllllllll}
\hline \multirow{2}{*}{ Catchment area } & \multicolumn{7}{c}{ Precipitation MCM/yr } & \multicolumn{3}{l}{ Flood runoff MCM/yr } & \multirow{2}{*}{ Remarks } \\
\cline { 2 - 8 } & Min. & Av. & Max. & Min. & Av. & Max. & \\
\hline Lower Jordan Valley eastern side wadis & 3186 & 4140 & 5092 & 123 & 250 & 422 & Including the Yarmouk River \\
Lower Jordan Valley eastern side wadis & 1215 & 1633 & 2049 & 27 & 68 & 129 & Excluding the Yarmouk River \\
Lower Jordan Valley eastern bottom area & 120 & 157 & 193 & 2.0 & 4.55 & 8.90 & Only the flat area of the Jordan Valley \\
Dead Sea eastern catchments & 938 & 1406 & 1874 & 17.3 & 49.6 & 101.1 & Including inter-wadi catchments \\
Wadi Araba eastern catchment & 253.4 & 455.1 & 648.6 & 1.18 & 9.40 & 26.3 & Including wadi Araba bottom catchments \\
Jafr & 455 & 671 & 887 & 2.28 & 10.1 & 26.6 & \\
Azraq & 730 & 1043 & 1356 & 1.46 & 12.5 & 32.50 & \\
Disi & 57.1 & 91.8 & 126.5 & 0.29 & 1.84 & 5.06 & \\
Durrah & 12.4 & 20.7 & 29.0 & 0.07 & 0.31 & 0.60 & \\
Hammad & 760 & 1118 & 1453 & 3.18 & 15.6 & 42.1 & \\
Sirhan & 370 & 515 & 750 & 1.48 & 7.2 & 24.0 & \\
\hline
\end{tabular}




\section{Results and Discussion}

\subsection{Changes in Precipitation and Runoff}

The results of the evaluation show the percentage changes in flood flows by changing precipitation amounts by $+10 \%,+20 \%-10 \%$ and $-20 \%$ relative to the long term averages of precipitation and the corresponding increases or decreases in the flood flows for the different catchment areas in Jordan (Table 2).

For Jordan, as a whole, a decrease in precipitation of $20 \%$ results in a decrease in flood runoff by $52.8 \%$ and a decrease in precipitation of $10 \%$ results in a decrease in flood runoff by $26.2 \%$. By an increase in precipitation by $10 \%$ the flood runoff will increase by $26.4 \%$ and by an increase in precipitation by $20 \%$ flood runoff will increase by $56.5 \%$. Figure 3 shows the Jordan main basins and sub-basins to illustrate the location and areas of each catchment in the study. Figure 4(a) and Figure 4(b) show the vertical profile from north to the south along the Jordan Valley (a) and Wadi Araba (b). No major differences in the precipitation-flood runoff ratios can be made between the different major catchment areas such as the Dead Sea, the Jordan Valley, Wadi Araba and the desert catchments. But it seems that the reactions of runoff to increases or decreases in precipitation amounts are more pronounced in the desert catchments and in the Dead Sea catchment, which partly extends eastward far into the desert areas such as in the cases of Mujib and Hasa catchments. Table A1 lists the amount of average precipitation water $(\mathrm{P})$ falling over the different catchments in $\mathrm{MCM} / \mathrm{yr}$, flood discharges in $\mathrm{MCM} / \mathrm{yr}$ and flood runoff/precipitation ratios (r) for the catchment areas all by $10 \%$ and $20 \%$ increases or decreases in precipitation.

Table 2. Summarizes the calculated increases or decreases in flood flow amounts in $\mathrm{MCM} / \mathrm{yr}$ as a result of increases or decreases in precipitation by $10 \%$ and $20 \%$ relative to the long-term average annual precipitation and flood flow amounts for the different areas of Jordan.

\begin{tabular}{ccccc}
\hline & \multicolumn{4}{c}{ Increase or decrease in $\boldsymbol{P}$} \\
\cline { 2 - 4 } Location & $-20 \%$ & $-10 \%$ & $+10 \%$ & $+20 \%$ \\
\cline { 2 - 4 } & Decreasing floods \% & Increasing floods \% \\
\hline All Jordan & -52.8 & -26.2 & 26.4 & 56.5 \\
Desert Areas & $-57--70$ & $-40--30$ & $26-41.8$ & $61-98$ \\
Desert Areas & $-57--64$ & $-31--33.5$ & $26-41.8$ & $75-90.3$ \\
Dead Sea & $-39.7--57$ & $-18.2--38$ & $22.2-43.6$ & $47.9-81$ \\
Dead Sea & $-41--45.7$ & $-26.2--32$ & $29.3-37$ & $52-60$ \\
Araba North & $-50--77$ & $-14.7--55$ & $27-47$ & $41-110$ \\
Araba North & $-50--71$ & $-21--30$ & $32.6-40$ & $49.6-69$ \\
Araba South & $-30--100$ & $-14.5--39$ & $16-142$ & $41-278$ \\
Araba South & $-36.4--56$ & $-21--30$ & $25-48$ & $43-103$ \\
Jordan Valley & $-46.5--93$ & $-27--68$ & $18-80$ & $56-189$ \\
Jordan Valley & $-52--66$ & $-31.6--53$ & $28-46.7$ & $80-110$ \\
\hline
\end{tabular}

* Without extreme values. 


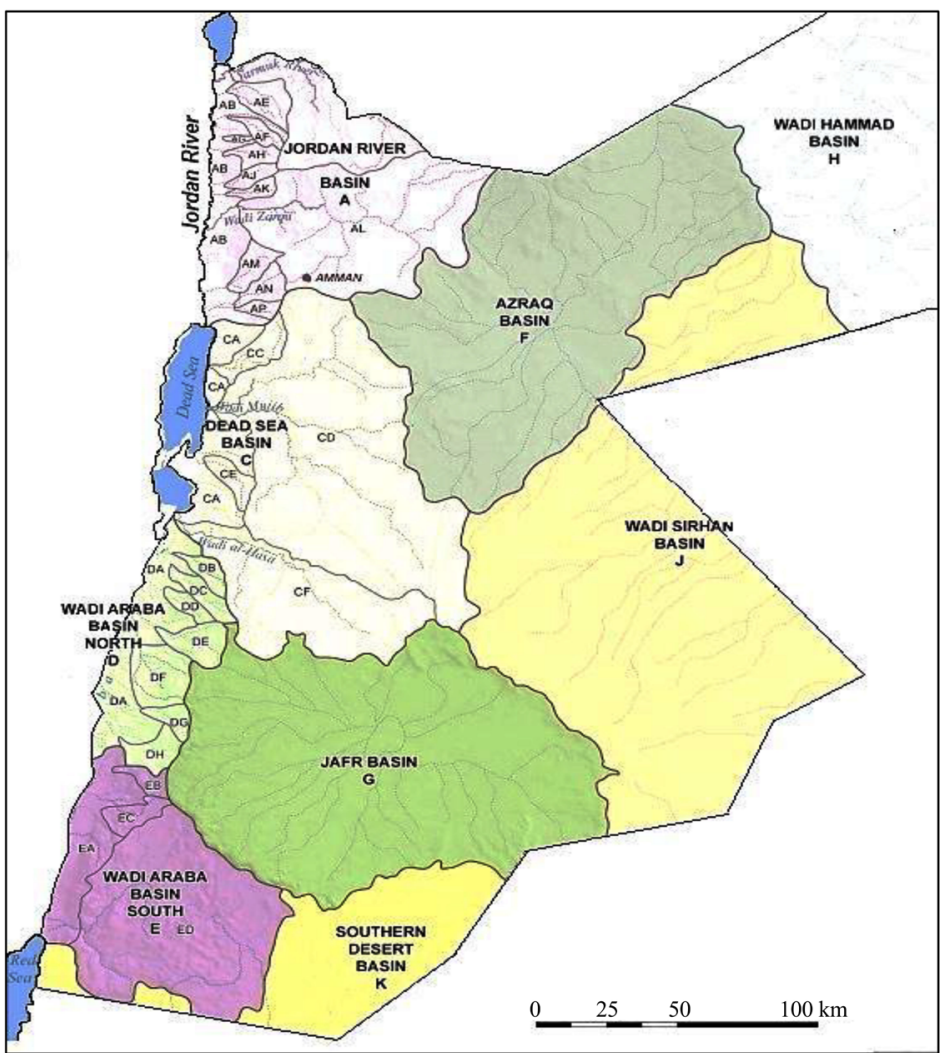

Figure 3. Jordan main and sub-water basins (after NWMP 1977and GIZ 2010).

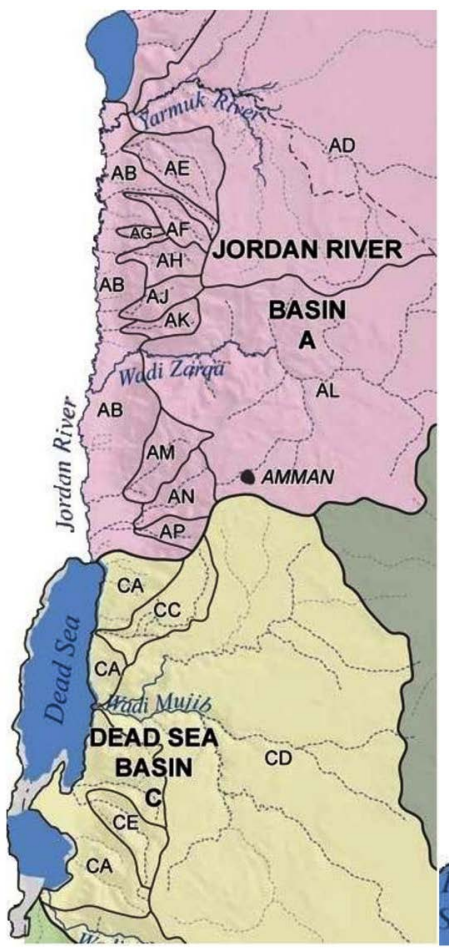

(a)

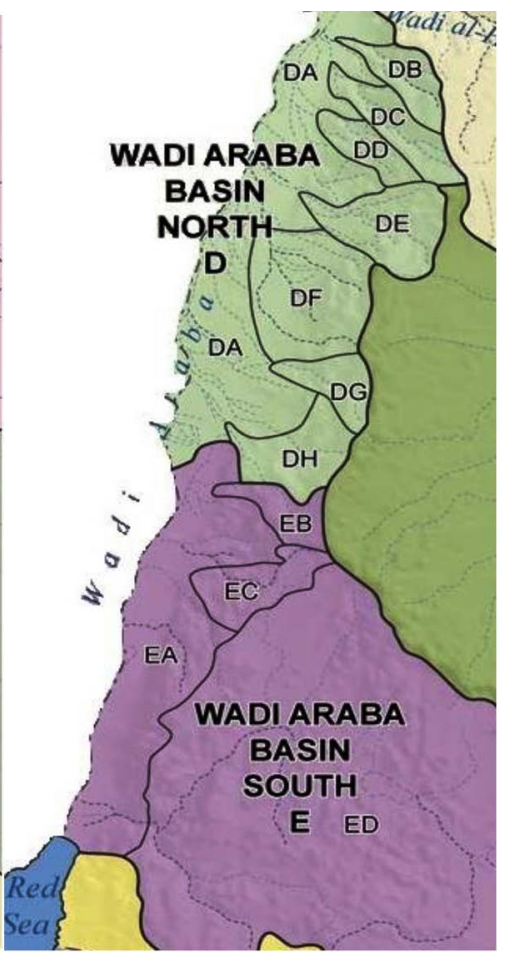

(b)

Figure 4. Vertical profile of main and sub-water basins: (a) along the Jordan Valley and (b) along Wadi Araba in the south (after NWMP 1977and GIZ 2010). 
Table 3 lists the calculated percentage changes in flood flows by changes in precipitation amounts by $+10 \%,+20 \%,-10 \%$ and $-20 \%$ of the long-term average precipitation for the different catchment areas in Jordan. It shows that a $10 \%$ decrease in precipitation over the different catchment areas will reduce flood flows by a minimum of $14.7 \%$ (Fifa catchment) and of 53\% (Kufranja catchment). By $20 \%$ reduction in precipitation, the minimum decrease in flood flows will be around 39\% in both the Jordan Valley inter-catchments and Mujib catchment and a maximum of $93 \%$ in the case of Yabis catchment. These reductions seem to be a function of the flatness of the catchment area. Increases in precipitation by $10 \%$ will produce an increase in flood flow by a minimum of $16 \%$ in Durrah catchment and an increase in precipitation by $20 \%$ will result in flood flow increases by around $42 \%$ in the case of Fidan Durrah and Yutum catchments. This result shows the sensitivity of the semiarid mountainous areas of Jordan to climate changes. Table 4 lists the changes in flood flow amounts in $\mathrm{MCM} / \mathrm{yr}$ as a result of decreasing or increasing amounts of precipitation by $10 \%$ and $20 \%$ relative to long-term averages and the corresponding flood flows for the different catchments in Jordan.

\subsection{Impacts on the Agricultural Sector}

\subsubsection{Rain-Fed Areas}

Rainfall distribution over Jordan for an average year is as follows:

- $1.350 \mathrm{~km}^{2}$ receive more than $500 \mathrm{~mm} / \mathrm{yr}$

- $1.629 \mathrm{~km}^{2}$ receive $300-400 \mathrm{~mm} / \mathrm{yr}$

- $11.250 \mathrm{~km}^{2}$ receive $200-300 \mathrm{~mm} / \mathrm{yr}$

- The rest $\left(75.188 \mathrm{~km}^{2}\right)$ receive less than $200 \mathrm{~mm} / \mathrm{yr}$.

In areas receiving more than $400 \mathrm{~mm} / \mathrm{yr}$ of precipitation reduction in precipitation over these areas by $10 \%$ or $20 \%$ will not have a major effect on their present use in agricultural production because these areas are planted by olives and other fruit trees which can tolerate $10 \%-20 \%$ reduction in the rainfall amounts.

Table 3. Calculated percentage changes in flood flows by changes in precipitation amounts by $+10 \%,+20 \%,-10 \%$ and $-20 \%$ of the long-term average precipitation for the different catchment areas in Jordan.

\begin{tabular}{lccccc}
\hline \multirow{3}{*}{ Area in Jordan } & & \multicolumn{4}{c}{ \% Increase or decrease in $P$} \\
\cline { 3 - 6 } & Catchment & $-20 \%$ & $-10 \%$ & $+10 \%$ & $+20 \%$ \\
\cline { 3 - 6 } & & Decreasing flood \% & Increasing flood \% \\
\hline \multirow{2}{*}{ Desert Areas } & Hamad H & -57 & -32 & 53 & 88 \\
& Sirhan I & -64 & -31 & 25.2 & 89 \\
& Azraq F & -70 & -40 & 41.8 & 90.3 \\
& Jafr G & -57.3 & -33.5 & 33.4 & 75.8 \\
& Disi K & -64 & -30 & 26 & 61 \\
\hline
\end{tabular}




\section{Continued}

\begin{tabular}{|c|c|c|c|c|c|}
\hline & Yarmouk AD & -47 & -27 & 18 & 56.6 \\
\hline & Arab AE & -52.2 & -30.4 & 29.2 & 61.6 \\
\hline & Ziglab AF & -46.5 & -31.8 & 36.4 & 80 \\
\hline & Jurm AG & -65 & -40 & 50 & 110 \\
\hline & Yabis AH & -93.0 & -68 & 42 & 80 \\
\hline & Kufranja AJ & -88 & -53 & 80 & 189 \\
\hline fordan vaney & Rajib-Zarqa AK-AL & -68 & -40 & 51 & 95 \\
\hline & Shueib AM & -60 & -31.6 & 32.8 & 92 \\
\hline & Kafrain AN & -66 & -38 & 46.7 & 133 \\
\hline & Hisban AP & -53 & -41 & 20 & 56 \\
\hline & Inter-catchments AB 21-26 & -39 & -19 & 41 & 74 \\
\hline & Inter-catchments AE-AP* & -62 & -35.3 & 50 & 92 \\
\hline & Zarqa Main CC & -56 & --32 & 37 & 79 \\
\hline & Wala CD1 & -41 & -26.7 & 22.2 & 52.6 \\
\hline & Mujib CD2 & -39.7 & -18.2 & 42.6 & 47.9 \\
\hline Dead Sea (DS) & Karak CE & -44.7 & -24.6 & 29.3 & 60.9 \\
\hline & Hasa CF & -45.7 & -25.3 & 31.3 & 55.8 \\
\hline & $\begin{array}{l}\text { DS inter-catchments } \\
\text { CA1-CA4 }\end{array}$ & -57 & -38.0 & 32 & 81 \\
\hline & DS Basins & -61.5 & -26.2 & 26.2 & 56.5 \\
\hline & GhaubaDA25 & -57 & -21 & 42 & 96 \\
\hline W.Araba & Fifa DB & -50 & -14.7 & 39 & 72.4 \\
\hline (North) & Khuneizir DC & -71 & -27 & 40 & 81 \\
\hline & Dahal DD & -77 & -55 & 47 & 110 \\
\hline & Fidan DE & -62.0 & -30.0 & 32.6 & 41.0 \\
\hline & Buweirde DF & -45.9 & -21.7 & 27 & 49.6 \\
\hline & W. Musa DG & -100 & -29 & 142 & 278 \\
\hline & Hawar DH & -55 & -28 & 48 & 103 \\
\hline & Darba EA25 & -30 & -14.5 & 25 & 43.6 \\
\hline Wadi Araba & Dilagha EB & -49 & -39 & 28.6 & 93.6 \\
\hline & Rakiya EC & -53 & -30 & 78 & 178 \\
\hline & Durrah K1 & -43 & -22 & 16 & 42 \\
\hline & Yutum ED & -44 & -25 & 18 & 41.8 \\
\hline & Ghauba to Boweirda & -36.4 & -24 & 20.5 & 65.2 \\
\hline & Musa W. Musa DG & -56 & -30 & 29.9 & 110 \\
\hline
\end{tabular}

${ }^{*}$ All above for the Jordan Valley area without the Yarmouk River. ${ }^{*}$ Jordan Valley inter-catchments. 
Table 4. Changes in flood flow amounts in MCM/yr as a result of decreasing or increasing amounts of precipitation by $10 \%$ and $20 \%$ relative to long-term averages of precipitation for all catchments in Jordan.

\begin{tabular}{|c|c|c|c|c|c|}
\hline \multirow{3}{*}{ Catchment area } & \multicolumn{5}{|c|}{$\%$ Change in precipitation } \\
\hline & $-20 \%$ & $-10 \%$ & Average & $+10 \%$ & $+20 \%$ \\
\hline & \multicolumn{5}{|c|}{ Flood flow amounts in $\mathrm{MCM} / \mathrm{yr}$} \\
\hline Sirhan & 2.6 & 5.0 & 7.21 & 10.75 & 14.3 \\
\hline Hammad & 6.7 & 10.6 & 15.6 & 24 & 29.5 \\
\hline Azraq & 3.75 & 7.5 & 12.52 & 17.75 & 23.8 \\
\hline Jafr & 4.3 & 6.7 & 10.07 & 13.43 & 17.7 \\
\hline Disi & 0.66 & 1.28 & 1.84 & 2.32 & 2.97 \\
\hline Yarmouk & 89.6 & 133 & 182 & 215 & 285 \\
\hline Arab & 3.19 & 4.51 & 6.8 & 8.37 & 10.5 \\
\hline Shueib & 0.7 & 1.21 & 1.77 & 2.53 & 3.4 \\
\hline Ziglab & 0.96 & 1.53 & 2.2 & 3.02 & 3.96 \\
\hline Jurm & 0.077 & 0.138 & 0.23 & 0.33 & 0.46 \\
\hline Yabis & 0.11 & 0.52 & 1.63 & 2.32 & 2.93 \\
\hline Kufranja & 0.12 & -0.48 & 1.02 & 1.82 & 2.95 \\
\hline Rajib & 0.42 & 0.79 & 1.31 & 1.98 & 2.55 \\
\hline Kafrain & 0.45 & 0.84 & 1.35 & 1.98 & 3.15 \\
\hline Hisban & 0.16 & 0.2 & 0.34 & 0.418 & 0.63 \\
\hline AE-AP & 6.22 & 10.6 & 16.33 & 24.5 & 31.1 \\
\hline AB21-AB26 & 2.76 & 3.67 & 4.54 & 6.42 & 7.91 \\
\hline Zarqa Ma'in & 1.3 & 2 & 2.96 & 4.5 & 5.32 \\
\hline Wala & 9.75 & 12.2 & 16.64 & 20.3 & 25.4 \\
\hline Mujib & 9.18 & 12.46 & 15.23 & 18.97 & 22.5 \\
\hline Hasa & 2.64 & 3.63 & 4.86 & 6.38 & 7.57 \\
\hline Karak & 1.69 & 2.38 & 3.17 & 4.1 & 5.1 \\
\hline Dead Sea basin & 19.1 & 26.6 & 49.60 & 62.7 & 77.6 \\
\hline CA1-CA4 & 0.44 & 0.6 & 1.03 & 1.36 & 1.87 \\
\hline Ghauba & 0.06 & 0.11 & 0.14 & 0.2 & 0.28 \\
\hline Fifa & 0.66 & 0.99 & 1.16 & 1.6 & 2 \\
\hline Khuneizira & 0.34 & 0.86 & 1.18 & 1.65 & 2.14 \\
\hline Dahal & 0.068 & 0.136 & 0.3 & 0.44 & 0.63 \\
\hline Musa & 0.004 & 0.1 & 0.14 & 0.34 & 0.53 \\
\hline Yutum & 0.78 & 1.06 & 1.41 & 1.67 & 2.1 \\
\hline Fidan & 0.5 & 0.92 & 1.32 & 1.75 & 2.29 \\
\hline Albuweirda & 1.32 & 1.91 & 2.76 & 3.1 & 3.65 \\
\hline Hawar & 0.132 & 0.21 & 0.29 & 0.43 & 0.59 \\
\hline Darba & 0.048 & 0.094 & 0.11 & 0.138 & 0.16 \\
\hline Dilugha & 0.1 & 0.143 & 0.22 & 0.35 & 0.43 \\
\hline Rakiya & 0.037 & 0.063 & 0.09 & 0.16 & 0.25 \\
\hline Durrah & 0.176 & 0.24 & 0.31 & 0.36 & 0.44 \\
\hline D22-D25 & 4.19 & 5.0 & 6.59 & 7.94 & 10.9 \\
\hline DF2-EB1 & 4.15 & 6.56 & 9.39 & 12.2 & 15.12 \\
\hline
\end{tabular}


Areas receiving an average of $350-400 \mathrm{~mm} / \mathrm{yr}$ will be affected by a reduction in precipitation and unless supplementary irrigation is provided the agricultural productivity of such areas will suffer, especially in dry to average rainfall years.

Areas receiving an average of $300-350 \mathrm{~mm} / \mathrm{yr}$ of precipitation, which are generally used to produce field crops such as wheat and barley, will suffer in a major way and will be turned into grazing land by a reduction in precipitation by $10 \%$ and $20 \%$.

Areas receiving an average of less than $300 \mathrm{~mm} / \mathrm{yr}$ which are presently used as grazing land will suffer from lower productivity of forage and hence their use as grazing areas will decrease. All in all the productivity of dry farming areas in Jordan will reduce by $10 \%$ and $20 \%$ by decreases in precipitation by the same percentages.

\subsubsection{Irrigated Areas}

Irrigated agriculture in Jordan consumes at present an average of around 550 $\mathrm{MCM} / \mathrm{yr}$ of water of which around $180 \mathrm{MCM} / \mathrm{yr}$ originate from treated wastewater, around $160 \mathrm{MCM} / \mathrm{yr}$ from flood flows and the rest from groundwater extraction. If precipitation over Jordan decreases by $10 \%$, flood flow will decrease by an average of $26.2 \%$ and in case of a decrease by $20 \%$ flood flow will decrease by $52.8 \%$. This means a reduction in the flood flow water used at present in irrigation of $160 \mathrm{MCM} / \mathrm{yr}$ to 118 and $75.5 \mathrm{MCM} / \mathrm{yr}$ respectively.

Because the total amount of water used in irrigation averaged during the last few years around $550 \mathrm{MCM} / \mathrm{yr}, 10 \%$ and $20 \%$ decreases in precipitation will leave only 508 and $465.5 \mathrm{MCM} / \mathrm{yr}$ for use in irrigation. This will result in around $8 \%$ and $15.4 \%$ reduction in the water amounts available for irrigation and hence irrigation products will also suffer of reduction by the same percentage, with all such reduction social and economic implications.

\section{Conclusion and Recommendation}

The common understanding that changes in precipitation amounts are reflected in flood water changes in about the same percentage seems to be a misleading concept and that is because the soils function as the storage medium for precipitation water according to soil infiltration capacities, precipitation frequency, type and intensity of precipitation and topography. Hence generation of flood flow is a function of all these parameters.

In Jordan precipitation and flood flows have been measured and calculated for the last 6 decades witnessing precipitation amounts of all ranges of extremely low to extremely high precipitation amounts. This enabled us to calculate flood runoff to precipitation ratios for a large number of years. The historical record allows using the calculation of flood runoffs of the different catchment areas in Jordan for precipitation increases or decreases by $10 \%$ and $20 \%$.

The results show that for Jordan, as a whole, precipitation decrease by $10 \%$ and $20 \%$ will result in $26.2 \%$ and $52.8 \%$ decrease in flood flows and precipitation increase by $10 \%$ and $20 \%$ will result in $26.4 \%$ and $56.5 \%$ increase in flood flows. 
The arid areas, especially the arid highlands of south Jordan will be stronger affected by both increasing and decreasing precipitation than other areas. That can be explained by their low precipitation amounts and illustrates the vulnerability of these areas to climate change. $10 \%$ less precipitation will cause $26 \%$ reduction in surface water availability for the irrigation, which in the case of Jordan amounts to around $42 \mathrm{MCM} / \mathrm{yr}$. Irrigated agricultural production will reduce by the same percentage $8 \%$. If precipitation decreases by $20 \%$ irrigation agricultural production will drop by $15.4 \%$.

In addition, around 7.000 people presently working in agriculture and consequently with their families ( 35.000 people) will join the poor's category if precipitation decreases by $10 \%$ and if it decreases by $20 \%$ the numbers will be 14.100 unemployed and 70.500 people added to the poor category. Increasing unemployment and poverty in the country may lead to social discomfort and unrest with all their implications on the political stability of the country. Therefore, proactive policies to alleviate the impacts of climate change are needed, which might include immediate programs and action plans to raise the level of water use efficiency in irrigation which is still an elastic water use sector.

Improved irrigation methods, better selection of crops requiring less water, applying plant water requirement principles and improving the efficiency of water conveyance on farm and of irrigation water supply systems are some of the actions that can alleviate the impacts of decreasing precipitation. Rainfed irrigation will also greatly suffer from reduced precipitation due to shifts of rain zones towards more avidity. Here also improving utilization of rain and overland flow water is required and better selection of dry-resistant crops with supplementary irrigation by treated wastewater can alleviate the implication of decreasing land productivity of rainfed areas with their impacts on employment, poverty and their social and political percussions.

Diminishing water resources as a result of climate change will force Jordan to either import water from outside the country (limited amounts) or to desalinate seawater at Aqaba for drinking purposes. Both solutions will put additional pressure on the economy of the country and socio-economic state of the population.

Such strong changes in the availability of stream runoffs as compared to changes in precipitation amounts are horrifying and somehow paradox, but that is what the history of precipitation and flood flow monitoring shows.

Jordan and other countries, especially those of arid and semi-arid climatic zones should prepare themselves for such climatic change, because these changes will strongly strike the peoples' economic situation, food security and employment with all the latter's ramifications to political system's stabilities.

In the case of Jordan, adapting to climate change impacts can somehow be achieved by intensive rain and floodwater harvesting and storage either in surface water structures or aquifers. In addition, increasing water use efficiency in agriculture by introducing more efficient water use and water conveyance systems, better choice of crops and applying plant-water requirement principles are 
sound programs to alleviate the climate changes effects. Due to increasing water stress resulting from increasing population and climatic changes Jordan ended having only one sound strategic option to mobilize adequate additional water resources and that is desalination of seawater at Aqaba. Since almost all the MENA countries are similar to Jordan in their climatic conditions, impacts of climate change and water stress abating climatic changes in these countries can follow the same recommendations mentioned above.

\section{Conflicts of Interest}

The authors declare no conflicts of interest regarding the publication of this paper.

\section{References}

Abdulla, F., \& Eshtawi, T. (2015). Climate Change Effect on Sediment Yield at King Talal Dam (Jordan). Civil and Environmental Research, 7, 13-26. http://www.iiste.org/Journals/index.php/CER/article/view/23741

Abu-Allaban, M., El-Naqa, A., Jaber, M., \& Hammouri, N. (2014). Water Scarcity Impact of Climate Change in Semi-Arid Regions: A Case Study in Mujib Basin, Jordan. Arabian Journal of Geosciences, 8, 951-959. https://doi.org/10.1007/s12517-014-1266-5

Alkhoury, W., Toll, M., Salameh, E., \& Sauter, M. (2009). Rainfall-Runoff Relationship in Micro-Scale Wadis in a Semi-Arid Environment-A Case Study from Wadi Kafrain in Jordan. In Proceedings of the 7th International Conference of the European Water Resource Association, Limassol, June 2009, 25-27.

Al-Zu'bi, Y. (2009). Application of Analytical Hierarchy Process for the Evaluation of Climate Change Impact on Ecohydrology: The Case of Azraq Basin in Jordan. Journal of Applied Sciences, 9, 135-141. https://doi.org/10.3923/jas.2009.135.141

Attour, I. S., \& Ibbitt, M. E. (1966). Flood Probabilities of the Yarmouk and Zarqa Rivers. Natural Resources Authority, Department of Research and Development, Professional Paper 1, Jordan.

Bany Yasin, H. (2018). The Case of the Hashemite Kingdom of Jordan. In ACT Alliance (Ed.), Enhanced Climate Action in Response to $1.5{ }^{\circ} \mathrm{C}$ of Global Warming. Scaling Up Nationally Determined Contributions (pp. 53-63). Geneva: ACT Alliance Secretariat. https://actalliance.org/wp-content/uploads/2018/11/ACT-Alliance_-Report-1.5C.pdf

Black, E. (2009). The Impact of Climate Change on Daily Precipitation Statistics in Jordan and Israel. Atmospheric Science Letters, 10, 192-200. https://doi.org/10.1002/asl.233

Chenoweth, J., Hadjinicolaou, P., Bruggeman, A., Lelieveld, J., Levin, Z., Lange, A., Xoplaki, E., \& Hadjikakou, M. (2011). Impact of Climate Change on the Water Resources of the Eastern Mediterranean and Middle East Region: Modeled 21st Century Changes and Implications. Water Resources Research, 47, W06506.

https://doi.org/10.1029/2010WR010269

Combaz, E. (2019). Jordan's Environmental Policies and Engagement on Climate Change.

EcoPeace Middle East (EcoPeace) (2019). Climate Change, Water Security, and National Security for Jordan, Palestine, and Israel.

https://www.hpacenter.org/uploads/editor/images/Climate\%20Change\%20\%2Cwater\% 20security $\% 20$ and $\% 20$ National\%20Security\%20for\%20Jorna\%20Palestine $\% 20$ and $\% 20$

\%C4\%B0srael\%20.pdf

Environmental Protection Agency (EPA) (2014). Climate Change Indicators in the Unit- 
ed States, USA (3rd ed.). EPA 430-R-14-004.

http://www.epa.gov/climatechange/indicators

German Technical Cooperation Agency (GIZ Formerly GTZ) (2010).

Hansen, E., \& Sato, M. (2011). Paleoclimate Implications for Human-Made Climate Change.

http://www.columbia.edu/ jeh1/mailings/2011/20110118_MilankovicPaper.pdf

Houghton, E. (1996). Climate Change 1995: The Science of Climate Change: Contribution of Working Group I to the Second Assessment Report of the Intergovernmental Panel on Climate Change (Vol. 2). Cambridge: Cambridge University Press.

Houghton, J. T., Jenkins, G. J., \& Ephraums, J. J. (1990). Climate Change: the IPCC Scientific Assessment. American Scientist (United States), 80.

IPCC (2007). Fourth Assessment Report: Working Group II Report "Impacts, Adaptation and Vulnerability". https://www.ipcc.ch/site/assets/uploads/2018/03/ar4_wg2_full_report.pdf

IPPC (2007). Climate Change. The Fourth Assessment Report of the Intergovernmental Panel on Climate Change (IPPC), Cambridge. https://doi.org/10.1017/CBO9780511546013

Japan International Cooperation Agency (JICA) \& Ministry of Planning (1987). Hydrogeological and Water Use Study of the Mujib Water Shed. JICA: FY 1985-1987.

McDonald, S. M., \& Partners in Cooperation with Hunting Geological Survey Limited (1965). East Bank Water Resources (p. 512). Amman: Natural Resources Authority.

Ministry of Public Works (MoPW) and Jordanian Consulting Engineers (JCE) (1992). Additional Flood Protection of Aqaba Back Road (65 p.). Central Tender No. 151/91.

Ministry of Water and Irrigation (MWI), Open Files.

National Water Master Plan of Jordan (NWMP) (1977). And Updates.

Odeh, T., Rödiger, T., Geyer, S., \& Schirmer, M. (2015). Hydrological Modeling of a Heterogeneous Catchment Using an Integrated Approach of Remote Sensing, a Geographic Information System and Hydrologic Response Units: The Case Study of Wadi Zerka Ma'in Catchment Area, Northeast of the Dead Sea. Environmental Earth Sciences, 73, 3309-3326. https://doi.org/10.1007/s12665-014-3627-5

Smadi, M., \& Zghoul, A. (2006). A Sudden Change in Rainfall Characteristics in Amman, Jordan during the Mid-1950s. American Journal of Environmental Sciences, 2, 84-91. https://doi.org/10.3844/ajessp.2006.84.91

Smiatek, G., Kunstmann, H., \& Heck, A. (2011). High Resolution Climate Change Simulations for the Jordan River Area. Journal of Geophysical Research: Atmospheres, 116, D16. https://doi.org/10.1029/2010JD015313

United Nations Development Programme (UNDP) (1992). Water Resources Politics, Planning and Management. Vol. 1, Surface Water Resources DP/UN/JOR/87/003, Amman.

USAID (2017). Climate Change Risk Profile. Jordan [Fact Sheet]. https://www.climatelinks.org/sites/default/files/asset/document/2017_USAID_Climate \%20Change\%20Risk\%20Profile_Jordan.pdf 


\section{Annex}

Table A1. Amounts of average precipitation water $(P)$ falling over the different catchments in MCM/yr and the amounts of precipitation, flood discharges, flood runoff/precipitation ratios $(r)$ for the catchment areas by $10 \%$ and $20 \%$ increases or decreases in precipitation.

(a)

\begin{tabular}{|c|c|c|c|c|c|c|}
\hline \multirow{2}{*}{ Area } & \multirow{2}{*}{ Parameters } & \multicolumn{5}{|c|}{ Increase or decrease in precipitation } \\
\hline & & $-20 \%$ & $-10 \%$ & Av. & $+10 \%$ & $+20 \%$ \\
\hline \multirow{7}{*}{$\begin{array}{l}\text { Yarmouk } \\
\text { AD total }\end{array}$} & $P[\mathrm{MCM}]$ & 2000 & 2256 & 2507 & 2758 & 3008 \\
\hline & $r[\%]$ & $4.8 \%$ & $5.9 \%$ & $7.3 \%$ & $7.8 \%$ & $9.5 \%$ \\
\hline & Flood discharges [MCM] & 96 & 133 & 182 & 215 & 285 \\
\hline & Flood discharges relative to average & -86 & -49 & 0.0 & 33 & 103 \\
\hline & Change in discharge as $\%$ of Av. & $-47 \%$ & $-27 \%$ & 0.0 & $18 \%$ & $56.6 \%$ \\
\hline & $P[\mathrm{MCM}]$ & 99.8 & 112.2 & 124.7 & 137.2 & 149.6 \\
\hline & $r[\%]$ & $3.2 \%$ & $4.2 \%$ & $5.2 \%$ & $6.1 \%$ & $7 \%$ \\
\hline \multirow[t]{5}{*}{ Arab AE } & Flood discharge [MCM] & 3.19 & 4.51 & 6.48 & 8.37 & 10.47 \\
\hline & Flood discharges relative to average & -3.38 & -1.97 & 0.0 & 1.9 & 4.0 \\
\hline & Change in discharge $\%$ of Av. & $-52.2 \%$ & $-30.4 \%$ & 0.0 & $29.2 \%$ & $61.6 \%$ \\
\hline & $P[\mathrm{MCM}]$ & 56.6 & 63.7 & 70.8 & 77.9 & 85 \\
\hline & $r[\%]$ & $1.3 \%$ & $1.9 \%$ & $2.5 \%$ & $3.3 \%$ & $4.0 \%$ \\
\hline \multirow{5}{*}{$\begin{array}{c}\text { Jordan } \\
\text { Valley area }\end{array}$} & Flood discharge [MCM] & 0.7 & 1.21 & 1.77 & 2.53 & 3.4 \\
\hline & Flood discharges relative to average. & -1.06 & -0.56 & 0.0 & 0.58 & 1.63 \\
\hline & Change in discharge $\%$ of Av. & $-60 \%$ & $-31.6 \%$ & 0.0 & 32.8 & $92 \%$ \\
\hline & $P[\mathrm{MCM}]$ & 41.9 & 47.2 & 52.4 & 57.6 & 62.9 \\
\hline & $r[\%]$ & $2.3 \%$ & $3.3 \%$ & $4.2 \%$ & $5.3 \%$ & $6.3 \%$ \\
\hline \multirow[t]{5}{*}{ Ziglab AF } & Flood discharge [MCM] & 0.96 & 1.53 & 2.2 & 3.02 & 3.96 \\
\hline & Flood discharges relative to average & -1.24 & -0.7 & 0.0 & 0.8 & 1.76 \\
\hline & Change in discharge $\%$ of Av. & $-46.5 \%$ & $-31.8 \%$ & 0.0 & $36.4 \%$ & $80 \%$ \\
\hline & $P[\mathrm{MCM}]$ & 7.68 & 8.64 & 9.6 & 10.6 & 11.52 \\
\hline & $r[\%]$ & $1.00 \%$ & $1.6 \%$ & $2.4 \%$ & $3.10 \%$ & $4.0 \%$ \\
\hline \multirow[t]{5}{*}{ Jurum AG } & Flood discharge [MCM] & -0.77 & 1.38 & 2.2 & 3.29 & 4.61 \\
\hline & Flood discharges relative to average & -1.43 & -0.88 & 0.0 & 1.09 & 2.4 \\
\hline & Change in discharge $\%$ of Av. & $-65 \%$ & $-40 \%$ & 0.0 & $50 \%$ & $110 \%$ \\
\hline & $P[\mathrm{MCM}]$ & 44.9 & 58.6 & 65.1 & 71.6 & 78.1 \\
\hline & $r[\%]$ & $0.3 \%$ & $0.9 \%$ & $2.5 \%$ & $3.3 \%$ & $3.8 \%$ \\
\hline \multirow[t]{3}{*}{ Yabis AH } & Flood discharge [MCM] & 0.11 & 0.52 & 1.63 & 2.32 & 2.93 \\
\hline & Flood discharges relative to average & -1.52 & -1.11 & 0.0 & 0.69 & 1.3 \\
\hline & Change in discharge $\%$ of Av. & $-93 \%$ & $-69 \%$ & 0.0 & $42 \%$ & $80 \%$ \\
\hline
\end{tabular}




\begin{tabular}{|c|c|c|c|c|c|c|}
\hline & $P[\mathrm{MCM}]$ & 48 & 54 & 60.2 & 66 & 72 \\
\hline & $r[\%]$ & $0.3 \%$ & $0.9 \%$ & $1.7 \%$ & $2.8 \%$ & $4.1 \%$ \\
\hline \multirow[t]{5}{*}{ Kufranja AJ } & Flood discharge [MCM] & 0.12 & -0.48 & 1.02 & 1.82 & 2.95 \\
\hline & Flood discharges relative to average & -0.9 & -0.54 & 0.0 & 0.8 & 1.93 \\
\hline & Change in discharge $\%$ of Av. & $-88 \%$ & $-53 \%$ & 0.0 & $80 \%$ & $189 \%$ \\
\hline & $P[\mathrm{MCM}]$ & 35 & 39.4 & 43.8 & 48.2 & 52.6 \\
\hline & $r[\%]$ & $1.2 \%$ & $2.0 \%$ & $3.0 \%$ & $4.1 \%$ & $4.9 \%$ \\
\hline \multirow[t]{5}{*}{ Rajib AK } & Flood discharge [MCM] & 0.42 & 0.79 & 1.31 & 1.98 & 2.55 \\
\hline & Flood discharges relative to average. & -0.89 & -0.52 & 0.0 & 0.67 & 1.24 \\
\hline & Change in discharge $\%$ of Av. & $-68 \%$ & $-39 \%$ & 0.0 & $51 \%$ & $95 \%$ \\
\hline & $P[\mathrm{MCM}]$ & 60 & 67.5 & 75 & 82.5 & 90 \\
\hline & $r[\%]$ & $0.8 \%$ & $1.3 \%$ & $1.8 \%$ & $2.4 \%$ & $3.5 \%$ \\
\hline \multirow[t]{5}{*}{ Kafrain AN } & Flood discharge [MCM] & 0.45 & 0.84 & 1.35 & 1.98 & 315 \\
\hline & Flood discharges relative to average & -0.9 & -0.51 & 0.0 & 0.63 & 1.8 \\
\hline & Change in discharge $\%$ of Av. & $-70 \%$ & $-40 \%$ & 0.0 & $46.7 \%$ & $133 \%$ \\
\hline & $P[\mathrm{MCM}]$ & 14.5 & 16.3 & 18.1 & 19.9 & 21.7 \\
\hline & $r[\%]$ & $1.1 \%$ & $1.3 \%$ & $1.9 \%$ & $2.1 \%$ & $2.9 \%$ \\
\hline \multirow[t]{5}{*}{ Hisban AP } & Flood discharge [MCM] & 0.16 & 0.2 & 0.34 & 0.418 & 0.63 \\
\hline & Flood discharges relative to average & -0.18 & -0.14 & 0.0 & 0.07 & 0.29 \\
\hline & change in discharge $\%$ of Av. & $-53 \%$ & $-41 \%$ & 0.0 & $20 \%$ & $56 \%$ \\
\hline & $P[\mathrm{MCM}]$ & 414.4 & 460 & 518 & 570 & 622 \\
\hline & $r[\%]$ & $1.5 \%$ & $2.3 \%$ & $3.1 \%$ & $4.3 \%$ & $5.0 \%$ \\
\hline \multirow[t]{5}{*}{$\mathrm{AE}-\mathrm{AP}^{*}$} & Flood discharge [MCM] & 6.22 & 10.6 & 18.50 & 24.5 & 31.1 \\
\hline & Flood discharges relative to average & -10.13 & -5.73 & 0.0 & 8.17 & 14.9 \\
\hline & Change in discharge $\%$ of Av. & $-60 \%$ & $-35.3 \%$ & 0.0 & $50 \%$ & $92 \%$ \\
\hline & $P[\mathrm{MCM}]$ & 12.5 & 141.2 & 156.9 & 172.6 & 188.3 \\
\hline & $r[\%]$ & $2.2 \%$ & $2.6 \%$ & $2.9 \%$ & $3.7 \%$ & $4.7 \%$ \\
\hline \multirow[t]{3}{*}{$\begin{array}{l}\mathrm{AB} 21 \text { - } \\
\mathrm{AB} 26^{* *}\end{array}$} & Flood discharge [MCM] & -2.76 & -3.67 & 4.54 & 6.42 & 7.91 \\
\hline & Flood discharges relative to average & -1.78 & -0.87 & 0.0 & 1.88 & 3.37 \\
\hline & Change in discharge $\%$ of Av. & $-39 \%$ & $-19 \%$ & 0.0 & $41 \%$ & $74 \%$ \\
\hline
\end{tabular}

*Without Yarmouk. 
(b)

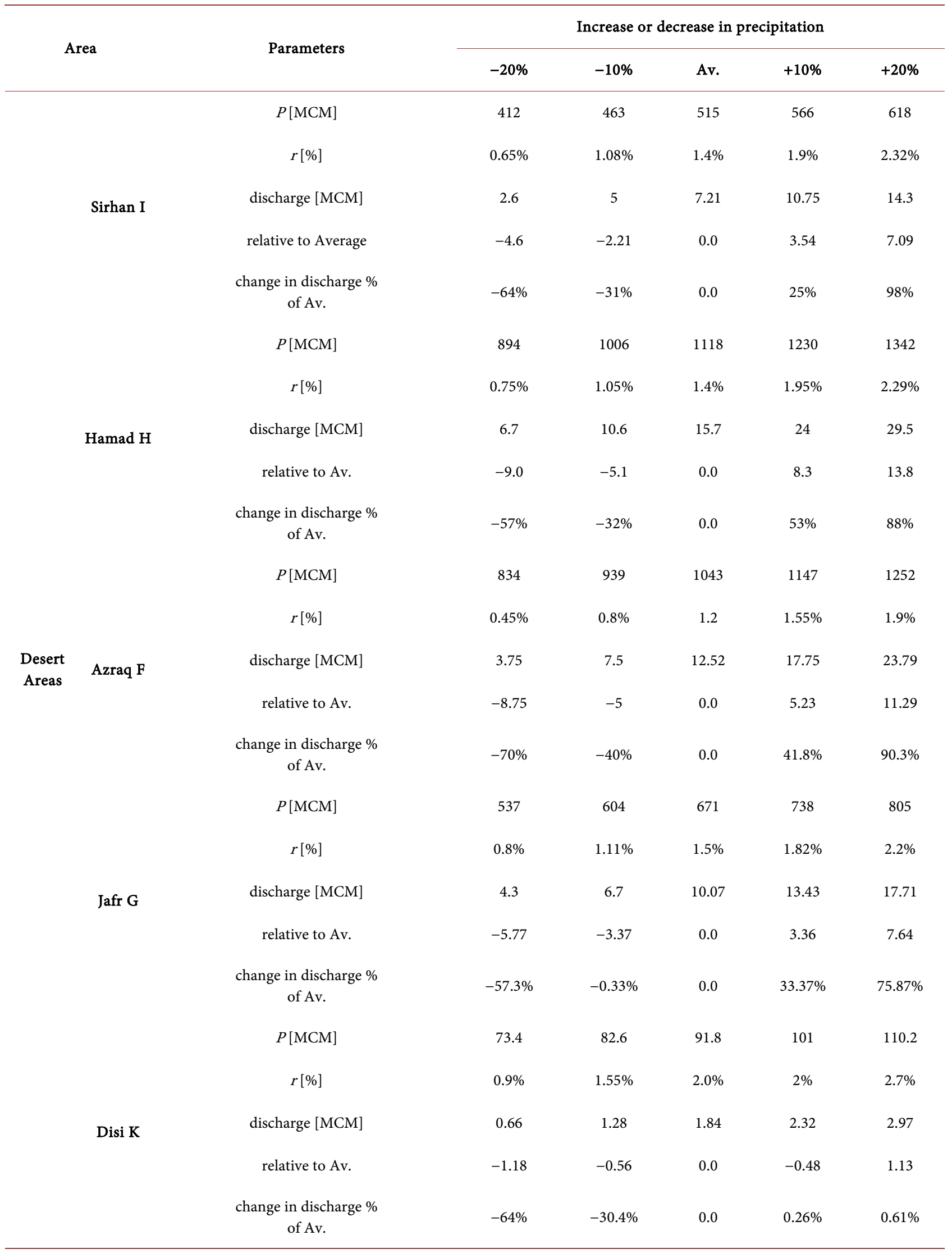


(c)

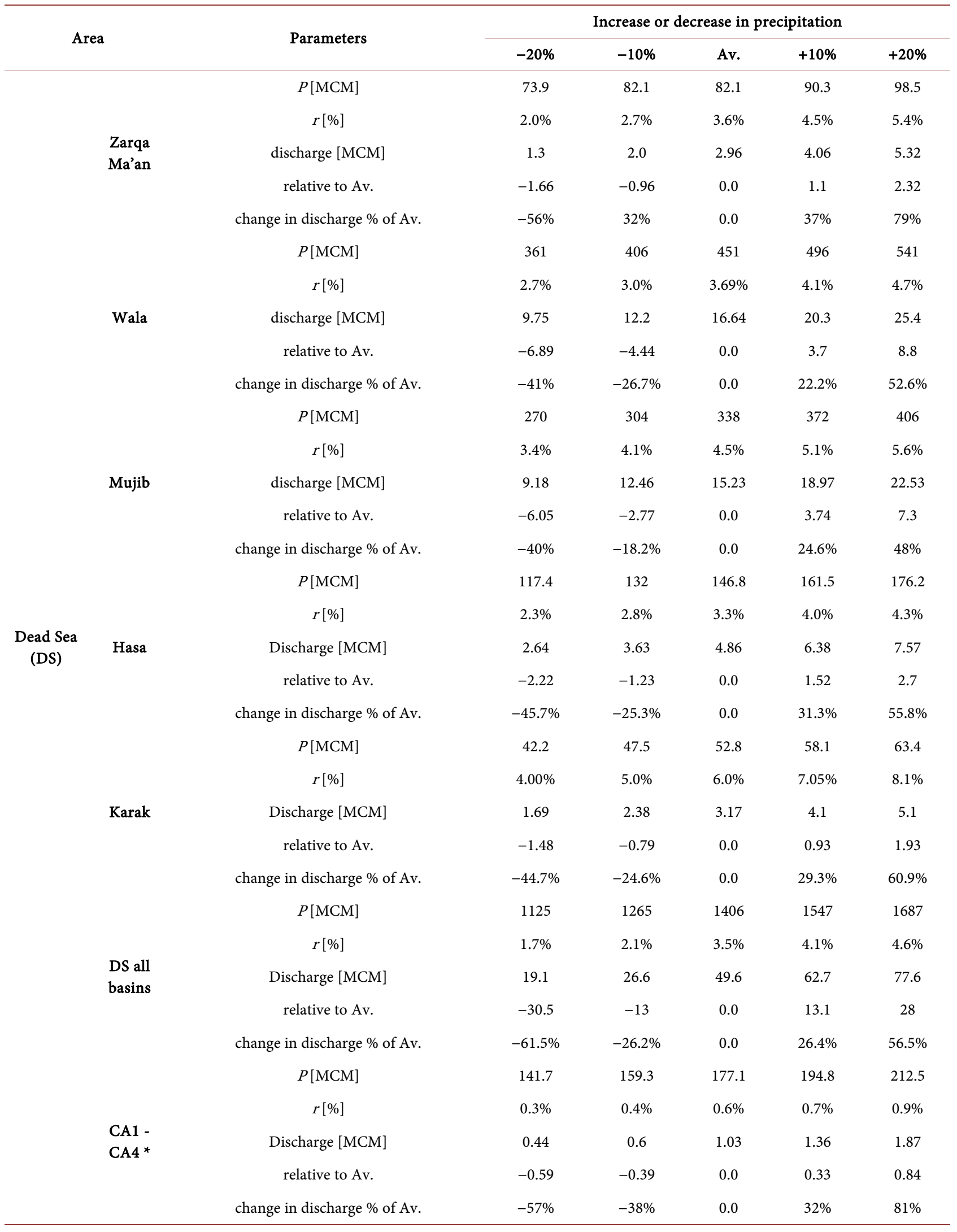

${ }^{*}$ Dead Sea side inter-catchments. 
(d)

\begin{tabular}{|c|c|c|c|c|c|c|c|}
\hline \multirow{2}{*}{\multicolumn{2}{|c|}{ Area }} & \multirow{2}{*}{ Parameters } & \multicolumn{5}{|c|}{ Increase or decrease in precipitation } \\
\hline & & & \multirow{2}{*}{$\begin{array}{c}-\mathbf{2 0 \%} \\
12.24\end{array}$} & \multirow{2}{*}{$\begin{array}{c}-10 \% \\
13.77\end{array}$} & \multirow{2}{*}{$\begin{array}{l}\text { Av. } \\
15.3\end{array}$} & \multirow{2}{*}{$\begin{array}{r}+10 \% \\
16.83\end{array}$} & \multirow{2}{*}{$\begin{array}{r}+20 \% \\
18.36\end{array}$} \\
\hline & & $P[\mathrm{MCM}]$ & & & & & \\
\hline & & $r[\%]$ & $0.50 \%$ & $0.80 \%$ & $0.90 \%$ & $1.20 \%$ & $1.50 \%$ \\
\hline \multirow{5}{*}{\multicolumn{2}{|c|}{ Ghauba }} & discharge $[\mathrm{MCM}]$ & 0.06 & 0.11 & 0.14 & 0.2 & 0.275 \\
\hline & & relative to Av. & -0.08 & -0.03 & 0 & 0.06 & 0.135 \\
\hline & & change in discharge $\%$ of Av. & $-57 \%$ & $-21 \%$ & $0.0 \%$ & $42 \%$ & $96 \%$ \\
\hline & & $P[\mathrm{MCM}]$ & 26.6 & 29.9 & 33.2 & 36.5 & 39.8 \\
\hline & & $r[\%]$ & $2.5 \%$ & $3.3 \%$ & $3.5 \%$ & $4.4 \%$ & $5.1 \%$ \\
\hline \multirow{5}{*}{\multicolumn{2}{|c|}{ Fifa }} & discharge $[\mathrm{MCM}]$ & 0.66 & 0.99 & 1.16 & 1.6 & 2 \\
\hline & & relative to Av. & -0.5 & -0.17 & 0 & 0.5 & 0.8 \\
\hline & & change in discharge $\%$ of Av. & $-50 \%$ & $-14.7 \%$ & $0.0 \%$ & $39 \%$ & $72.4 \%$ \\
\hline & & $P[\mathrm{MCM}]$ & 28.5 & 32 & 35.6 & 39.2 & 42.7 \\
\hline & & $r[\%]$ & $4.2 \%$ & $2.7 \%$ & $3.3 \%$ & $4.2 \%$ & $5.0 \%$ \\
\hline \multirow{5}{*}{\multicolumn{2}{|c|}{ Khuneizir }} & discharge $[\mathrm{MCM}]$ & -0.34 & -0.86 & 1.18 & 1.65 & 2.14 \\
\hline & & relative to Av. & -0.84 & -0.32 & 0 & 0.47 & 0.96 \\
\hline & & change in discharge $\%$ of Av. & $-71 \%$ & $-27 . \%$ & $0 \%$ & $40 \%$ & $81 \%$ \\
\hline & & $P[\mathrm{MCM}]$ & 15.1 & 17.01 & 18.9 & 20.8 & 22.7 \\
\hline & & $r[\%]$ & $0.5 \%$ & $0.8 \%$ & $0.3 \%$ & $2.1 \%$ & $2.8 \%$ \\
\hline \multirow[t]{18}{*}{ Wadi Araba } & Dahal & Discharge [MCM] & 0.068 & 0.136 & 1.6 & 0.44 & 0.63 \\
\hline & & relative to Av. & -0.23 & -0.16 & 0 & 0.14 & 0.33 \\
\hline & & change in discharge $\%$ of Av. & $-77 \%$ & $-55 \%$ & 0 & $47 \%$ & $110 \%$ \\
\hline & & $P[\mathrm{MCM}]$ & 22.2 & 24.9 & 27.7 & 30.5 & 33.2 \\
\hline & & $r[\%]$ & $0.20 \%$ & $0.4 \%$ & $0.5 \%$ & $1.10 \%$ & $1.6 \%$ \\
\hline & Musa & Discharge [MCM] & 0.004 & 0.1 & 0.14 & 0.34 & 0.53 \\
\hline & & relative to Av. & -0.01 & -0.04 & 0 & 0.2 & 0.39 \\
\hline & & change in discharge $\%$ of Av. & $-100 \%$ & $-29 \%$ & $0.0 \%$ & $142 \%$ & $2.8 \%$ \\
\hline & & $P[\mathrm{MCM}]$ & 53.76 & 60.5 & 67.2 & 73.9 & 80.6 \\
\hline & & $r[\%]$ & $1.45 \%$ & $1.8 \%$ & $2.1 \%$ & $2.26 \%$ & $2.6 \%$ \\
\hline & Yutum & Discharge [MCM] & 0.78 & 1.06 & 1.41 & 1.67 & 2.1 \\
\hline & & relative to Av. & -0.63 & -0.35 & 0 & 0.26 & 0.59 \\
\hline & & change in discharge $\%$ of Av. & $-44.7 \%$ & $-25 \%$ & $0.0 \%$ & $18.0 \%$ & $41.8 \%$ \\
\hline & & $P[\mathrm{MCM}]$ & 52.6 & 59.2 & 65.8 & 72.4 & 79 \\
\hline & & $r[\%]$ & $95.00 \%$ & $1.6 \%$ & $2.0 \%$ & $2.42 \%$ & $2.9 \%$ \\
\hline & Fidan & Discharge [MCM] & 0.5 & 0.92 & 1.32 & 1.75 & 2.29 \\
\hline & & relative to Av. & -0.82 & -0.4 & 0 & 0.43 & 0.54 \\
\hline & & change in discharge $\%$ of Av. & $-62 . \%$ & $-30 . \%$ & $0.0 \%$ & $32.6 \%$ & $41 \%$ \\
\hline
\end{tabular}




\section{Continued}

\begin{tabular}{|c|c|c|c|c|c|c|}
\hline & $P[\mathrm{MCM}]$ & 43.4 & 48.9 & 54.3 & 59.7 & 65.2 \\
\hline & $r[\%]$ & $3.05 \%$ & $3.9 \%$ & $4.5 \%$ & $5.20 \%$ & $5.6 \%$ \\
\hline \multirow[t]{5}{*}{ El Boweirda } & Discharge [MCM] & 1.32 & 1.91 & 2.44 & 3.1 & 3.65 \\
\hline & relative to Av. & -1.12 & -0.53 & 0 & 0.66 & 1.21 \\
\hline & change in discharge $\%$ of Av. & $-45.9 \%$ & $-21.7 \%$ & $0.0 \%$ & $27 \%$ & $49.6 \%$ \\
\hline & $P[\mathrm{MCM}]$ & 26.3 & 29.6 & 32.9 & 36.2 & 39.5 \\
\hline & $r[\%]$ & $0.5 \%$ & $0.7 \%$ & $0.9 \%$ & $1.8 \%$ & $1.5 \%$ \\
\hline \multirow[t]{5}{*}{ Hawar } & Discharge $[\mathrm{MCM}]$ & 0.132 & 0.21 & 0.29 & 0.43 & 0.59 \\
\hline & relative to Av. & -0.16 & -0.08 & 0 & 0.14 & 0.3 \\
\hline & change in discharge $\%$ of Av. & $-55 \%$ & $-28 \%$ & 0 & $48.0 \%$ & $103.0 \%$ \\
\hline & $P[\mathrm{MCM}]$ & 5.9 & 0.7 & 7.4 & 8.14 & 8.8 \\
\hline & $r[\%]$ & $1.3 \%$ & $1.4 \%$ & $1.5 \%$ & $1.7 \%$ & $1.8 \%$ \\
\hline \multirow[t]{5}{*}{ Darba } & Discharge [MCM] & 0.048 & 0.094 & 0.11 & 0.138 & 0.158 \\
\hline & relative to Av. & 0.033 & 0.016 & 0 & 0.028 & 0.048 \\
\hline & change in discharge $\%$ of Av. & $30 \%$ & $14.5 \%$ & $0.0 \%$ & $25 \%$ & $43.6 \%$ \\
\hline & $P[\mathrm{MCM}]$ & 8.48 & 9.54 & 10.6 & 11.66 & 12.72 \\
\hline & $r[\%]$ & $1.3 \%$ & $1.5 \%$ & $2.0 \%$ & $3.0 \%$ & $3.4 \%$ \\
\hline \multirow[t]{5}{*}{ Dilugha } & Discharge [MCM] & 0.1 & 0.143 & 0.22 & 0.35 & 0.426 \\
\hline & relative to Av. & -0.114 & -0.087 & 0 & 0.13 & 0.206 \\
\hline & change in discharge $\%$ of Av. & $-49 \%$ & $-39 \%$ & 0 & $28.6 \%$ & $93.6 \%$ \\
\hline & $P[\mathrm{MCM}]$ & 18.6 & 21 & 23.3 & 25.6 & 28 \\
\hline & $r[\%]$ & $0.2 \%$ & $0.3 \%$ & $0.4 \%$ & $0.6 \%$ & $0.9 \%$ \\
\hline \multirow[t]{5}{*}{ Rakiya } & Discharge [MCM] & 0.037 & 0.063 & 0.09 & 0.16 & 0.252 \\
\hline & relative to Av. & -0.053 & -0.027 & 0 & 0.028 & 0.25 \\
\hline & change in discharge $\%$ of Av. & $-53 \%$ & $-30 \%$ & $0.0 \%$ & $25 \%$ & $178 \%$ \\
\hline & $P[\mathrm{MCM}]$ & 16.6 & 118.6 & 20.7 & 22.8 & 24.8 \\
\hline & $r[\%]$ & $1.1 \%$ & $1.3 \%$ & $1.5 \%$ & $1.6 \%$ & $1.8 \%$ \\
\hline \multirow[t]{5}{*}{ Durrah } & Discharge [MCM] & 0.176 & 0.24 & 0.31 & 0.36 & 0.44 \\
\hline & relative to Av. & -0.134 & -0.068 & 0 & 0.05 & 0.13 \\
\hline & change in discharge $\%$ of Av. & $-43 \%$ & $-22 \%$ & $0.0 \%$ & $16 \%$ & $42 \%$ \\
\hline & $P[\mathrm{MCM}]$ & 186.2 & 209.4 & 232.7 & 256 & 279.2 \\
\hline & $r[\%]$ & $1.9 \%$ & $2.4 \%$ & $2.8 \%$ & $3.1 \%$ & $3.9 \%$ \\
\hline \multirow[t]{5}{*}{$\mathrm{D} 22-\mathrm{D} 25^{*}$} & Discharge $[\mathrm{MCM}]$ & 4.19 & 5 & 6.59 & 7.94 & 10.9 \\
\hline & relative to Av. & -2.4 & -1.59 & 0 & 1.35 & 4.3 \\
\hline & change in discharge $\%$ of Av. & $-36.4 \%$ & $-24 \%$ & $0.0 \%$ & $20.5 \%$ & $65.2 \%$ \\
\hline & $P[\mathrm{MCM}]$ & 360.8 & 410 & 451.1 & 496.1 & 541.2 \\
\hline & $r[\%]$ & $1.2 \%$ & $1.6 \%$ & $2.0 \%$ & $2.5 \%$ & $2.8 \%$ \\
\hline \multirow{3}{*}{$\begin{array}{l}\text { DF2 - } \\
\text { EB } 1^{* *}\end{array}$} & Discharge [MCM] & 4.15 & 6.56 & 9.39 & 12.2 & 5.12 \\
\hline & relative to Av. & -5.24 & -2.83 & 0 & 2.81 & 10.3 \\
\hline & change in discharge $\%$ of Av. & $-56 \%$ & $-30 \%$ & $0.0 \%$ & $29.9 \%$ & $100 \%$ \\
\hline
\end{tabular}

